\title{
Basotho Women Migrants : a Case Study
}

Judith S. Gay

The majority of Basotho men go to South Africa as migrant workers while the majority of Basotho women remain as dependent wives in Lesotho. At least half of Lesotho's adult male labour force is involved in migrant work, an estimated 180,000 to

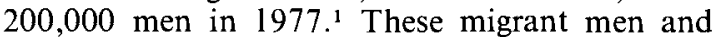
their dependents have been the focus of most of the literature on Lesotho's labour problems. Yet Basotho women too have migrated, and in Southern Africa as elsewhere women migrants have been neglected in the literature and under-estimated in the statistics [IDS 1979: 18-19].

According to the 1976 national census figures, 9.4 per cent of Lesotho's population who were in wage employment in South Africa were female or, as Figure 1 shows, 15.4 per cent of total absentees. An even higher percentage of total absentees were female during the period before 1960 when women could live as dependents or employees in South Africa without legal restriction.

In the rural lowlands village of Lesotho on which this paper is based, 20.6 per cent of the 433 women over age 17 either had worked in South Africa in the past, or were doing so in 1977, and many others had lived there for a time with relatives. A proper understanding of the impact of migrant labour on Lesotho must take account of the experiences of such women migrants as well as of the women who have remained in Lesotho as dependents of male migrants.

Because female migrants are a concern neither of the mine labour recruiting agencies nor of Lesotho's Department of Labour, there are few national statistics and no detailed studies. In this paper I focus on 94 women from a single village who have been or still are part of the female migrant labour force. I consider their reasons for going to South Africa, the type of work done, the restrictions imposed on female migrants, and the social impact of their migrant experience.

\footnotetext{
1 The data for this article were collected as part of field research on the impact of migrant labour on rural women conducted in Lesotho during 1976-77 under the supervision of the Department of Anthropology, Cambridge. The author would like to express appreciation for financial assistance from The Smuts Memorial Fund and Sir Bartle Frere's Memorial Fund which helped to make this research possible.
}

\section{Women and Migrant Labour Theory}

The pattern of oscillating migration which characterises Lesotho's economy has been analysed by Francis Wilson, according to a model showing the forces which preserve the oscillation between urban and rural areas [Figure 2, after Wilson 1972: 144-56]. Other studies of migrant labour within the Southern African economic system have explored the means whereby the dominant capitalist mode of production has sought to retain the cheapest possible compliant black labour force and hence the reproduction of the entire economic system by the under-development of the rural reserve areas and the enforced periodic repatriation of black workers [Legassick 1974; Wolpe 1972; Perrings 19771. As these authors argue, the history of South Africa in the past 30 years is the story of the legal, political and ideological developments of apartheid to maintain this socio-economic system.

This paper considers the impact of the Southern African economic system on women. This is implicit, but not fully developed, in each analysis. Wilson's model assumes that if the push and pull factors are maintained the labour force continues to circulate. But to the extent that women themselves participate in circulatory migrant labour they no longer guarantee a dependable domestic base in the rural areas. In so far as women are allowed to become settled urban dwellers in South Africa, either as permanent workers or as wives living with husbands and children, they threaten the entire oscillating system and the structure of apartheid which maintains it. Prevention of female migration appears to be a necessary condition for the preservation of circulatory male migration under conditions which threaten to dissolve the subsistence mode of production and the rural social system and hence undermine the continuing reproduction of cheap male labour [Wolpe 1972: 425]. Thus continued migrant labour of men depends upon 'influx control' restrictions. These prevent women from responding to rural push and urban pull forces and push them permanently out of the towns, relegating them to the rural areas. Figure 2 (item b) is a modification of Wilson's model as it applies to women in Southern Africa. It indicates how apartheid legislation intensifies urban push forces and blocks female response to rural push and urban pull forces which continue to be felt. This 


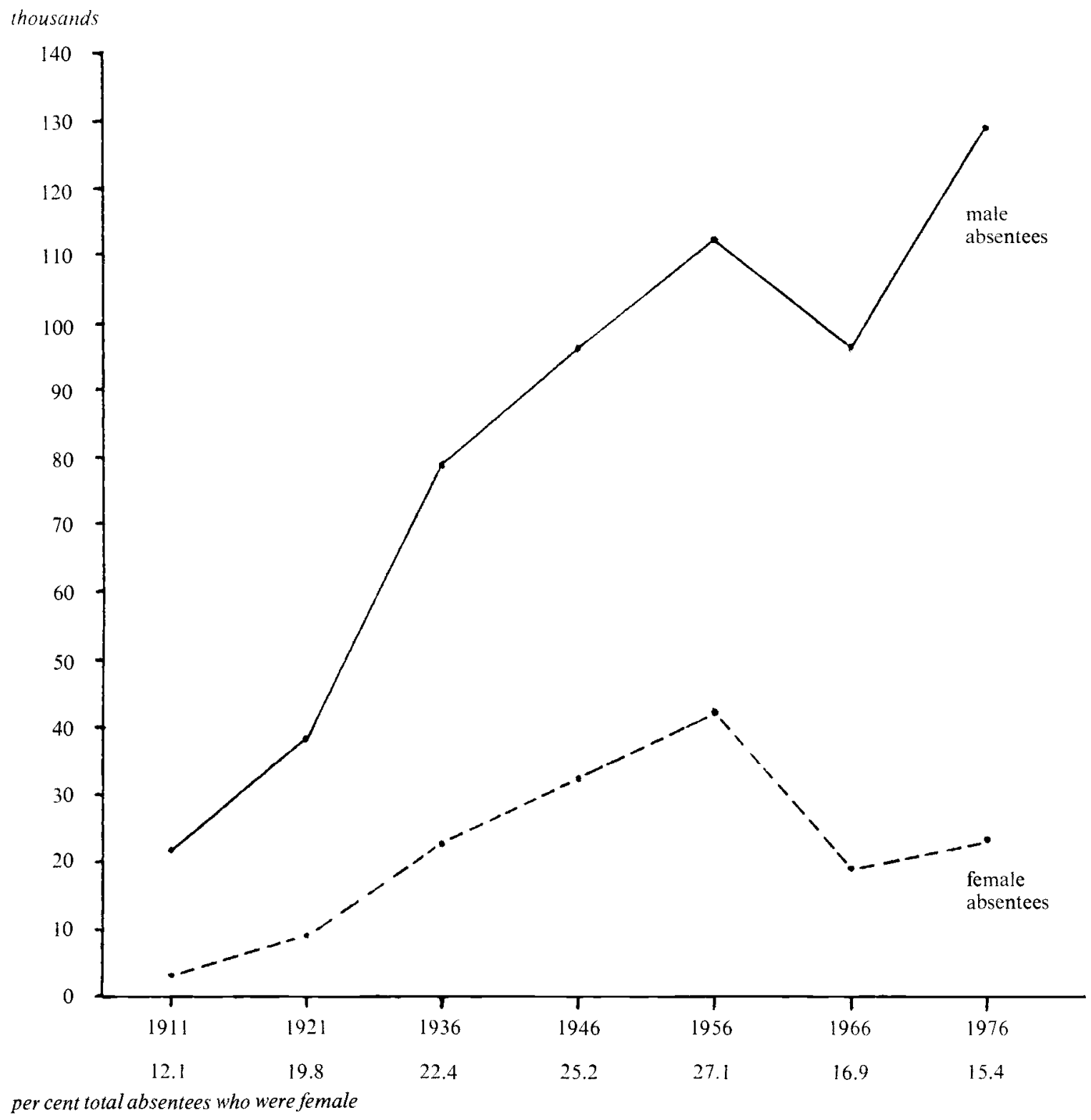

Source: Based on census reports summarised in Monyake, 1974, and on unpublished preliminary tabulations of the 1976 census.

* In 1966, absentees were defined as 'persons away from Lesotho continuously for less than five years'. This strict definition partly explains the drop in absentees in that year. However, a comparison of male and female absentees indicates the differential effect of 1960 and 1963 South African restrictions on female dependents and workers. 
leads to a sense of deep frustration on the part of many younger rural women who cannot now seek work in the Republic as did Basotho women of the older generation.

\section{Migrant Workers and Family Relations}

In order to understand the factors which led certain women to respond to the pull of South African employment we must consider briefly the economic and marital circumstances of typical village women.

\section{Dependent wives of migrants}

In the village studied, 150 of the 433 women over age 17 are migrants' wives. Of the 296 households, 38.9 per cent are headed by such wives when their migrant husbands are away; other younger wives are living in the households of their husbands' parents. Many migrants' wives complain that husbands do not send sufficient money. Some receive none for long periods, and some say that their husbands have simply disappeared, leaving them technically married but with no financial support. A study by van der Wiel showed that miners spent an average of 41 per cent of their annual earnings of R839 on themselves and the rest was sent or taken home through deferred pay, cash and goods to be shared among many relatives [van der Wiel 1977: 82]. The average migrant's wife receives only a small share of the man's earnings for household expenses. Many wives must therefore seek other means to supplement irregular remittances and the minimally productive subsistence agriculture on Lesotho's impoverished land (of which only 13 per cent is arable).

Co-resident husbands and wives

Some married couples reside together within the village because the husband is either retired, ill, home on extended leave, farming or working in Lesotho. In 197727.7 per cent of the village household heads were resident men, but most of these were earning little or no regular cash income.

\section{Women without husbands}

The third major group of women are those living without husbands. Unmarried, separated and divorced women normally live in their own natal homes or seek wage employment if they have children to support. Widows remain in their husbands' homes. In 1977, 33.4 per cent of the household heads were women without husbands, primarily widows who depend on wage-earning sons or their own income generating efforts.

\section{Women as migrants}

Although present political conditions prevent most Basotho women from going into South Africa for work, it was not so in the past. A population pyramid for the village is given in Figure 3, indicating past and present migrant experience. Although few young women are migrants, 36.1 per cent of the women over age 39 have had some work experience in South Africa. Similar data were reported by van Drunen from Northern Lesotho. She observed that older migrants:

keep the aspirations of women directed towards wage employment by talking about those times . . . adding to the frustration already felt by the young women because they are completely dependent on the husbands' whims and willingness to provide and because they are denied the experience of $a$ job and a life in the industrial modern world.

[van Drunen 1977:23]

Figure 2 Dynamics of oscillating migrant labour from Lesotho*

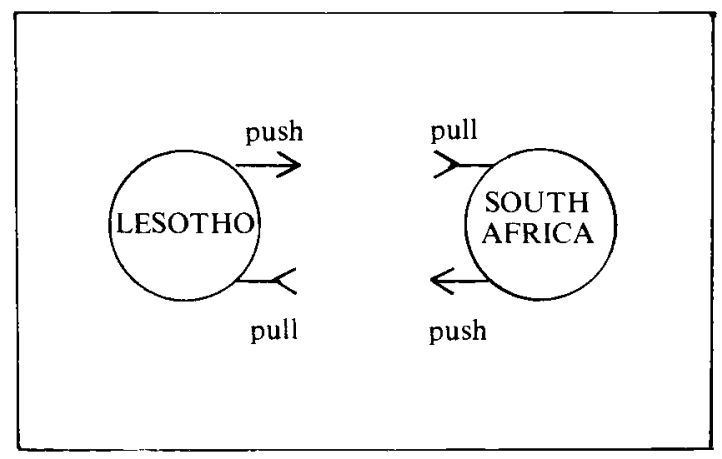

a. Continuing male migration

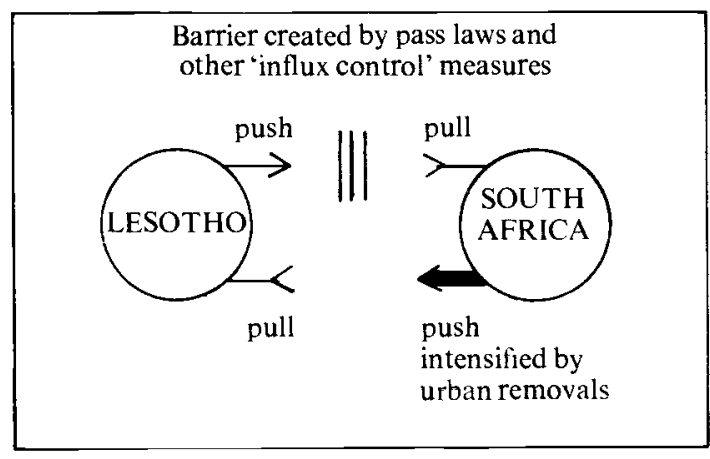

b. Disrupted female migration

*Indicating the differential effects on men and women of South African 'influx control' measures [after Wilson 1972 : 144-56] 


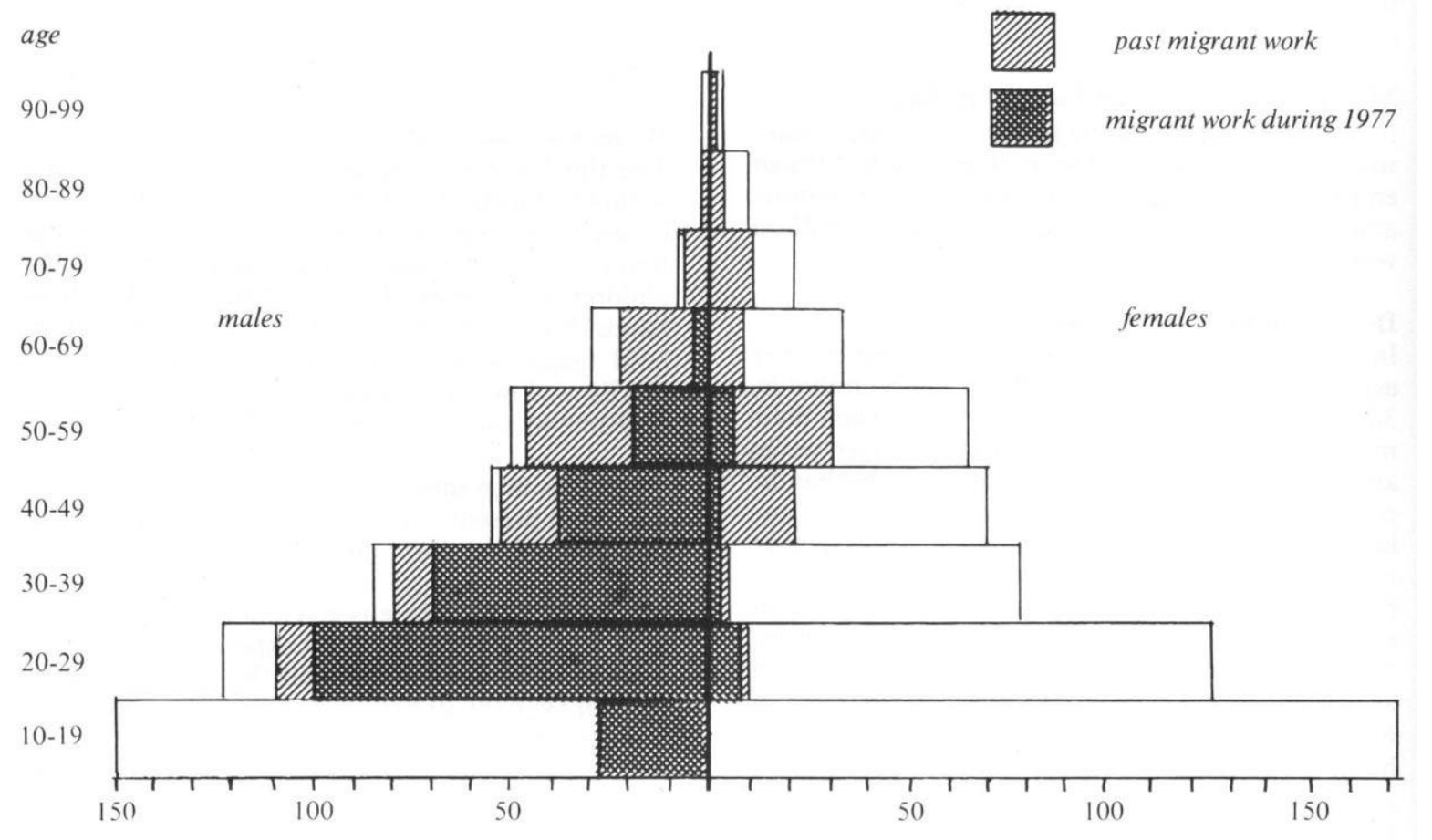

The women who went

Of the 74 village women who had worked in South Africa in the past, some began work before they were married. They had grown up as children of migrants, or they went for a few years before marriage seeking experiences and earning opportunities which they could not find in Lesotho.

Some women went as married adults together with their husbands to work on the farms of the Orange Free State or Cape Colony, particularly during the periods of drought, dust and famine of the 1930s. A few of these couples returned to resettle in Lesotho: they had earned sufficient to purchase livestock, or they wished to educate their children, or were forced out by restrictions which curtailed the rights of black families in rural areas. However, a number of these women remained for most of their lives working as domestics for white farm families even if their husbands died or disappeared, drawn away by the higher wages in the mines and cities.

Apart from the few young girls and the couples who went to work together, most women migrants were without husbands, forced by economic and marital problems to leave the village and seek work. Nearly a quarter of the women who worked in
South Africa are now separated or divorced, while others remain technically married but have not lived with their husbands for years: 15 per cent said they had gone in the first place because their marriages had dissolved, their husbands had taken other wives, or because they had been barren and hence rejected. In other cases it was the birth of an illegitimate or adulterine child which led the women to leave home. For all those women in difficulty because of their unsuccessful relations with men, employment in the Republic offered both an alternative to the frustrations of rural life and the means to support their children and make a fresh start in a new community.

The last group of women on their own are older widows who went to seek work only after their husbands had died, leaving them with children but with inadequate assets in Lesotho to manage without a cash income.

Thus, although the majority of Basotho women are wives of migrants, most of those who went to South Africa to work were women on their own. Monica Wilson wrote that in the 1930s in urban South Africa: 
the deserted and deserting wives form the nucleus of a very large class... which is swelled by numbers of unwed mothers and widows . . . driven by poverty to come to town to earn money to support their children and themselves.

[Wilson 1936: 484]

Both Basotho men and women who sought work in South Africa were driven by economic necessity as the need for cash grew and the yields from agriculture declined. But for women, this economic necessity was inseparable from their insecurity as dependents upon long-absent migrant workers, and the difficulty of building strong cooperative marital relationships under migrant labour conditions.

\section{The work of migrant women}

Of the 74 village women who had worked in South Africa in the past, 55 reported that they had done regular domestic work for at least some period. Seven had worked in factories or shops and three had done full-time agricultural work, although many more had done occasional agricultural jobs. Nine women said they had never been regularly employed but had made a living by brewing and selling illicit beer and by sewing and doing 'piecejobs'; many others with regular employment had supplemented their wages by brewing.

None of these women found the opportunity for more skilled employment or further education in South Africa. The double discrimination of sex and race meant that then (as now) it was almost exclusively in their domestic roles that black women could obtain employment. However, the domestic lives of these women were split. Cleaning, washing, child-minding and cooking could be sold on the legitimate labour market in the service of white family life. Brewing, sewing, sex and hospitality could provide supplementary income in the 'informal sector' serving the needs of black workers separated from their own families. But the care of their own children had to be delegated to others if they were to earn the money to support them.

\section{Legal restrictions on women migrants}

Throughout the 20th century black women who sought to live and work in white-controlled South Africa have faced a growing body of legal restrictions, particularly regarding brewing, housing and passes [Horrell 1978].

Older women told how they had once lived in their own homes or the homes of friends or relatives in urban South Africa. But municipal authorities resisted this influx of Africans to the urban areas, asserting as early as 1921 that: the town is a European area in which there is no place for the redundant Native who neither works, nor serves his or her people, but forms the class from which the professional agitators, the slum landlords, the liquor sellers, the prostitutes and other undesirable classes spring.

[Native Affairs Commission 1921, cited in Wilson and Thompson, 1969 II: 187]

In 1923 the Natives (Urban Areas) Act was passed, the first of a long series of measures to restrict African residence in urban areas. The years following the rise of the National Party to power in 1948 have seen the destruction of shanty-towns and freehold settlements and the removal of black workers to rigidly controlled and policed locations and single-sex hostels. Many of the older village women said the homes they had once lived in had been destroyed and they themselves had been 'endorsed out'. This process of 'urban removals' is bound up with the ever more elaborate pass laws whereby the rights of blacks to travel, live and work in the Republic have been progressively curtailed. Pass laws now affect all Africans within the Republic, but fall particularly hard upon women, children and old people who are regarded as 'superfluous appendages' to the African labour force [Froneman, cited in Bernstein 1978: 12]. The pass system was extended to women for the first time by legislation in 1952 .

Despite a period of political resistance by women in the 1950s, many Basotho working women eventually accepted these 'Malan passes' and remained, but others were forced to return to Lesotho by 1960. Additional restrictions were imposed, and after 1963 'foreign blacks' could remain working in South Africa only with passports from their own countries and under the most limited circumstances: if they had worked 10 continuous years for one employer or a total of 15 continuous years, or if they could obtain special 'no objection' certificates from a Bantu Labour Bureau allowing them to work. This legislation affected women in particular because, whereas men have continued to be actively recruited for mine work and thus have permits arranged for them, there is absolutely no legal recruitment of women within Lesotho. Even women who obtain 14-day visitors' visas are not legally allowed to seek employment.

Today only a few Basotho women qualify under the above conditions. Most women who now go to work must obtain documents illegally, or take the risk of clandestine travel and work without legal permission. In July 1979 an amendment to the Bantu Urban Areas Act raised the fine for those who employ 'illegal blacks' to $£ 260$. This is ex- 
pected to lead to the dismissal of thousands of foreign black employees such as these Basotho women [Laurence 1979].

Although the legal restrictions on Basotho women migrants are imposed by the South African Government, Basotho men themselves have not been altogether happy about 'their women' working away from home. In 1908 Basotho men complained to the British administration about women 'absconding' and seeking refuge and work across the border where husbands found difficulties in getting them back [British Government 1908]. Similar complaints were heard in Natal in 1906 from men who objected that colonial laws allowed 'their girls to run off to towns and, under the pretext of work, lead a loose life' [Wilson and Thompson 1969 II: 215$]$.

In 1947 the Paramount Chief of Lesotho issued a circular 'forbidding women and children to proceed to the Union, especially to Johannesburg, in view of the shortage of accommodation there' [Sheddick 1954: 191, citing Paramount Chief's Circular no 10/47]. And after South Africa imposed its legal restrictions of 1963, Lesotho's own Department of Labour has not allowed any South African recruitment of women, even for brief seasonal agricultural work. As one Department of Labour official explained: 'The question of women working in a foreign country is a delicate issue and . . . as long as a women is under somebody, we do not want to be involved'. Similarly, a woman who wants to take out a passport must have the signature of the male kinsman whom she is under, for otherwise, a passport official said, 'she could just run away'.

Thus, Basotho women are under a double constraint: restricted as ever by the traditional malecontrolled society, and prevented by the machinery of South African 'influx control' from leaving that society. All that most of them can now do is to remain on South Africa's periphery, reproducing its labour force, doing unpaid domestic work, cultivating impoverished fields, seeking low-paid local employment, providing a market for South Africa's products, and becoming increasingly dependent on undependable male wage earners.

\section{Present female migration}

Despite the legal restrictions, a substantial number of Basotho women were still migrating in 1977 , although whether they can circumvent the newest regulations of 1979 remains to be seen. As in the period before 1963, these migrants tend to be women on their own, driven by economic and marital problems and the difficulty of finding employment within Lesotho. Twenty women from the village were working in South Africa in 1977. Four were unmarried, three widowed, 12 separated or divorced and one married; all but three had children to support.

A few women from Lesotho who continue as migrants do have legal passports and work permits, but most simply go illegally and run the risks involved, returning across the border river after a year or two of work. Such women dare not complain about low wages and poor working conditions. They fear to appear in public places lest they encounter the police, and they dare not risk their jobs by taking leave and crossing the border more often than necessary. These 20 women spent an average of only 1.8 weeks per year on home leave, in contrast to 8.7 weeks for migrant men. The circumstances under which they work are far more precarious than conditions for male migrants and the wages are much lower. But women continue to go when they are desperate because wages are higher than those available in Lesotho.

As in the past, most of the women who continue as migrants find work as domestics, although often in the poorest rural white, and urban non-white, households. Of the 20 women, one is a sales clerk, one a weaver, one a nun, two work in factories, one brews full-time and the other 14 are domestic servants.

\section{Social Relations of Women Migrants}

Traditional social relations were modified and new types of relations developed among migrant women as they sought to survive under difficult circumstances, living as women on their own apart from friends, natal kin, husbands, in-laws and children.

Self-reliance. Most of these women had made a conscious choice to leave rural life and travel long distances alone to seek work. They grew accustomed to making their own decisions, handling their own money, solving their own problems, and living alone in tiny servants' quarters. Indeed, they were more on their own than contract mine workers whose every action is controlled by labour recruiters, employers, 'boss boys' and 'Indunas'.

Women friends and women's groups. Wherever women went they formed friendships with other migrant women: co-workers, neighbours, or simply older women speaking the same language who recognised a younger country-woman alone in the big city and offered help with housing, food, advice and job-hunting.

Working women formed many kinds of associations, re-creating in new ways in the urban environ- 


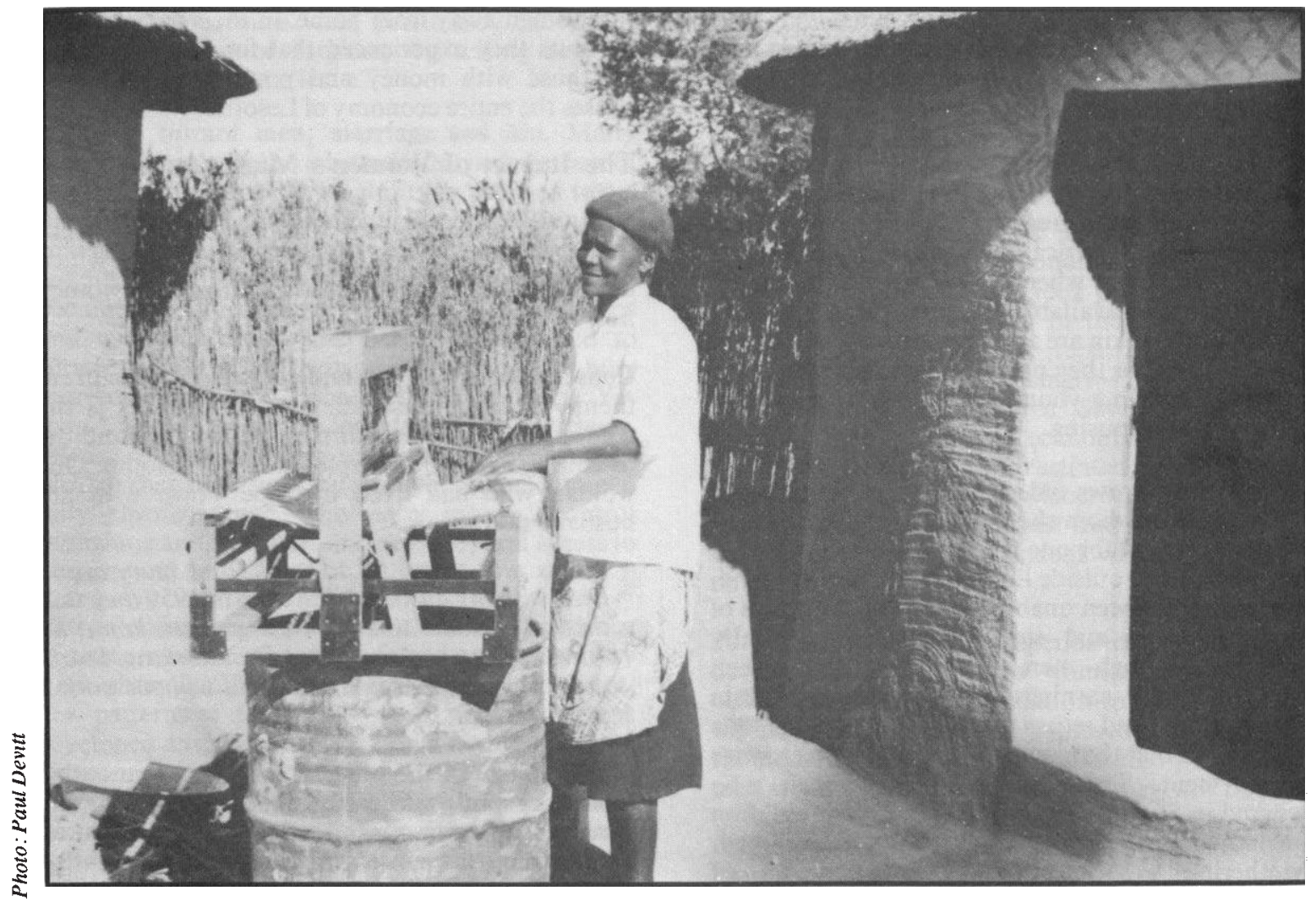

ment the types of female cooperative work, exchange, and support relations which were important in village life. There were church groups, burial associations, knitting cooperatives, rotating credit and savings associations for pooling salaries, and brewing groups which shared a common social life and the profits from their sales.

Husbands and male friends. We have seen that for most of the women who went to work in South Africa the marriage bond was either non-existent, undependable, or a positive handicap. Many husbands would not allow their wives to take paid employment, fearing the broadened social contacts and the independence a woman feels when she has control of her own money. For those women who went to work, the South African towns provided alternatives to traditional marriage which tended to undermine male-controlled social structures, but which opened up new possibilities for women's emancipation, productive work and participation in the modern world.

Certainly for those women who went to South Africa because normative marriage did not exist, or in order to escape a marriage they felt to be oppressive, sexual and emotional relations with men continued to be important. But these liaisons were usually temporary affairs which women could make and break with a degree of autonomy utterly unknown in traditional marriage. I believe that many such women came to see men, who were themselves suffering from the strains of the migratory labour systems, as undependable but exploitable: as a resource which could be used to meet their immediate needs, but not as dependable partners with whom they could hope to build close conjugal relations and stable homes.

Natal kin and children. While migrant labour has weakened both conjugal and affinal relations, it has tended to strengthen relations between a woman and her own natal kin. The patrilineal family system remains, providing the underlying structures of citizenship, property and land rights, and the social security system on which migrants depend. But for many women the norm of marriage and gradual incorporation as a wife into the husband's lineage is less important than the dependable ties with their own parents, siblings and child- 
ren. This is particularly true for women who have worked in South Africa, and for those women who now turn to the urban areas of Lesotho to seek employment.

Genealogies collected in the village reveal chains of matrilaterally linked daughters, mothers, grandmothers and even great-grandmothers who have worked in South Africa, the younger woman being able to go to work when her mother or other natal kinswoman is available to care for her young children. Natal kin are also important if they live in South Africa, for they often provide the initial contacts which help a young woman from Lesotho to find work and housing.

As a woman grows older, it is primarily her own children upon whom she must depend. This is particularly crucial for one who has lived most of her life on her own, outside Lesotho without a husband, and hence has been unable to build up the assets of fields, housing and stock which are normally acquired through men. Many migrant women spend all their earnings to support and educate their children and return to care for their daughter's children so that the daughter in turn may seek wage employment. Thus, even though women who worked in South Africa had to leave their children behind, a pattern of matrifocality developed. Mothering was interrupted by a number of working years and delegated to matrilateral kinswomen, but remained the dominant motive for going to work and the mechanism which made such work possible.

Among the most tragic cases are those of women who are financially unable to give up their jobs, yet conceive another child and turn to dangerous illegal abortion or to infanticide, or simply give the child away to any woman who will give it a home. The bearing of children continues, but the nature of the female labour system demands that the domestic roles of women who are serving the white population be rigidly separated from their reproductive roles.

Employers. Since the majority of rural Basotho women migrants have worked as domestic servants, their most intimate day-to-day relations have been with their white employers. Some spoke of their frustrations at living under apartheid and being constantly under command, criticised and prevented from living their own lives. On the other hand, some women became heavily dependent on employers who gave them food, old clothes, medicine and even brandy, instead of adequate wages and respect. Despite their automony as single work- ing women away from home, in their daily lives as servants they experienced that forced dependency on those with money and power which characterises the entire economy of Lesotho.

\section{The Impact of Women's Migration on Rural Life}

The experience of past work and life in South Africa and the type of social relations which developed have had a significant impact on women now living in Lesotho

Consciousness of unemployment. A recurrent theme of interviews with former migrants is the contrast between their former self-reliance and the discouraging lack of employment in Lesotho. One woman who had lived in Cape Town with her husband said:

it was nice there. I had work, and money, and lived with my husband. But then in 1959 they said that all Basotho women must go back home. So now I am just sitting here and not working. I want work but I cannot find any. And without work a person cannot live.

The ideology of the migrant labour system is that women are fully occupied with subsistence agriculture and domestic tasks in their rural homes, releasing men for mine and industrial labour. But those women who have had the experience of being paid for their domestic labour, and thus of participating as workers in the cash economy, feel the pain of being forcibly unemployed on the rural periphery.

Consumer orientation. Most women migrants come back with very little property or savings and without the resources, skills or interest to engage in rural agriculture, but with a knowledge of white affluence and of what money can buy. As these women worked and shopped alongside English and Afrikaner housewives they acquired white consumer values and styles of house-keeping, cooking and dress, which are in evidence in rural villages throughout Lesotho. The result is an increased need for the products of South African industry and agriculture, a devaluation of Basotho women's traditional productive activity, and an increased dependence upon South Africa.

Brewing. The women who came back brought with them modifications of one of the oldest female skills - brewing sorghum beer. The brewing groups, the rotating credit associations, the blaring jive music from record players, and the swinging life and prostitution associated with urban shebeens are an increasing feature of rural life, as women 
attempt to maximise what profit they can make from cultivation of sorghum by selling beer to migrant men on home leave.

Attitudes toward men, marriage and kin. Many women brought home a bitterly-learned distrust of relations with men, but an ability to use men to get the cash they need. Their migrant experiences as well as the general instability of marriage under the conditions of migrant labour have led women to become heavily dependent on female friendships and natal kin links, and fiercely determined to support and educate their own children, who may represent their only hope of future security. Yet they live with the knowledge that, as they themselves are excluded from wage employment, much of what they need for rural survival can be obtained only through men who earn money, control ploughing and livestock, and provide rural access to housing and fields.

Patron-client relations. Despite the independence of those women who were forced to break away from their families and seek wage employment, new patterns of dependency upon wealthy patrons developed after years of working for white masters. Economic stratification among Basotho is not new; loans of cattle, use of fields and assurance of protection were basic to the establishment of the Basotho nation and of individual chief's powers. But the pattern of dependence on whites which characterises employment in South Africa undermines self-confidence and increases the dependency of rural women, who are denied the right to productive work and economic self-sufficiency.

Political consciousness. Many women migrants returned with bitter experiences of racial discrimination, police harassment, economic exploitation and involvement with black political protest in South Africa in the 1950s and early 1960s. Women who continue as migrant workers express mixed feelings toward the events in Soweto in 1976 and the escalating liberation struggle. They share the longing for improved wages and housing and freedom from pass laws, but are fearful that political unrest will jeopardise their already limited chance to work. Today many rural women appear to be completely apolitical, lulled by South African radio propaganda, fearful to express themselves in Lesotho, and anxious only for the money to survive. But those who have worked in South Africa often bear a smouldering resentment against the economic and social injustice which they have experienced.

\section{The Future for Rural Basotho Women}

Women who went as migrants and returned, as well as those who remain in Lesotho as dependents of absent migrants, have had to develop an extraordinary degree of independence and self-reliance. What remains to be seen is in which direction the future developments in Southern Africa will push them.

The increasing dependence of women on male earnings leads to greater economic control by men over their families despite long periods of separation. But present cutbacks in the recruitment of migrants may lead to the repatriation and unemployment of an increasingly large portion of Basotho's male labour force. Severe strains may result on the political and economic, as well as on the domestic level, as frustrated migrant men attempt to rediscover a place within Lesotho's economy, and to reassert their traditional domestic control over these independent wives and daughters.

Patterns of female independence which have developed in response to women's double subordination as blacks in relation to whites, and as women in relation to men, represent a force which should not be lost. It is only as Basotho women and men work together as equals that they will be able to find that genuine interdependence upon which political freedom, just economic relations, and healthy family lives, can be reconstructed.

\section{References}

Bernstein, Hilda, 1978, For Their Triumphs and for Their Tears, International Defence and Aid Fund, London

Gay, Judith S., 1980, Basotho Women's Options: a Study of Marital Careers in Rural Lesotho, Phd dissertation, University of Cambridge

British Government, 1908, Annual Colonial Reports: Basutoland, no 556, 1906-7

Horrell, Muriel, 1978, Laws Affecting Race Rela'tions in South Africa: 1948-76, South Africa Institute of Race Relations, Johannesburg

IDS, 1979, 'The Continuing Subordination of Women in the Development Process', Bulletin, vol 10 no 3, IDS Sussex (Kate Young ed)

Laurence, Patrick, 1979, 'Koornhoff pays the price for lenience', The Guardian, 19 July

Legassick, Martin, 1974, 'South Africa: capital accumulation and violence', Economy and Society, vol 3 
Monyake, A. M. (ed), 1974, Kingdom of Lesotho: Report on the National Population Symposium, Maseru, Lesotho

Perrings, Charles, 1977, 'The theory of labour migrancy', National University of Lesotho, mimeo

Sheddick, Vernon, 1954, Land Tenure in Basutoland, Colonial Research Studies 13, Her Majesty's Stationery Office, London

van der Wiel, A. C. A., 1977, Migratory Wage Labour: Its Role in the Economy of Lesotho, Mazenod Book Centre, Mazenod, Lesotho van Drunen, Laetitia, 1977, Lesotho: Village Life and Migrant Labour, dissertation, University of Utrecht

Wilson, Francis, 1972, Migrant Labour in South Africa, The South African Council of Churches and SPRO-CAS, Johannesburg

Wilson, Monica (Hunter), 1936, Reaction to Conquest, Oxford University Press, London

Wilson, Monica and Leonard Thompson, 1969, The Oxford History of South Africa, Clarendon Press, Oxford

Wolpe, H., 1972, 'Capitalism and cheap labourpower in South Africa: from segregation to apartheid', Economy and Society, vol 1 